\title{
Sea level rise impacts on coastal zones: "soft" measures to cope with it
}

\begin{abstract}
Sea level rise impacts are projected to cause multiple negative consequences in coastal zones such as coastal erosion, flooding, flood-related health problems, property damage, and socio-economic impacts. Thus, it is imperative to assess adaptation measures to minimize these devastating projections. Several strategies that respond to sea level rise (such as Retreat, Accommodate, Protect) have been developed. Within the Protect Responsive Strategy, "hard" and "soft" adaptation options have been widely implemented in coastal zones. This paper examines several "soft" adaptation options (beach nourishment, dune restoration, afforestation and reforestation, and marine soft engineering technology), which provide interesting possibilities in response to sea level rise in coastal zones. Advantages and disadvantages of these "soft" options are analyzed from an ecological and socio-economic perspective. The paper concludes with proposed recommendations that could support "soft" structure approaches in coastal zone areas.
\end{abstract}

\begin{abstract}
About the Author: Paola Cisneros completed a BSc (Hons) in Biology in 2004 at Universidad Nacional Mayor de San Marcos, Lima, Peru. Also, she obtained her specialization in Hydrobiology and Fisheries in 2007 at Universidad Nacional Mayor de San Marcos, Lima, Peru. She is a current candidate in the Master of Marine Management program at Dalhousie University and will graduate in August 2012. Paola has a strong interest in adaptive responses to climate change effects and coastal zone management. This essay was originally written for a class called "Independent Reading Course" (MARA 5005.03)
\end{abstract}




\section{Introduction}

Coastal zones are valuable for several reasons. They help to regulate the environment, support community livelihoods, provide shelter, aesthetic and recreational opportunities for people, and protect fragile marine habitats for flora and fauna (Intergovernmental Panel of Climate Change, 1996). However, their integrity is being threatened by both anthropogenic activities (Muniz et al., 2004, Mato et al., 2001) and by an increase in the frequency and intensity of extreme natural events (e.g. tropical cyclones such as hurricanes and typhoons) due to climate change (Meehl et al., 2007). According to the Intergovernmental Panel of Climate Change (1996), sea level rise is the most hazardous result of climate change in coastal zones. Negative effects attributed to sea level rise include shoreline erosion and coastal storm flooding. However, there are also secondary impacts that could cause major damage. For example, flood-related health problems (e.g. anxiety, depression, respiratory/chest illness, skin irritation) (Tunstall, Tapsell, Green, Floyd \& George, 2006), property damage (Gornitz, Couch \& Hartig, 2002), lost of crop fields (Sarwar \& Khan, 2007) and others socio-economic activities (Sarwar \& Khan, 2000; Bosello, Roson \& Tol, 2007).

Three response strategies have been developed to address sea level rise: retreat, accommodation, and protection (Figure 1) (Intergovernmental Panel of Climate Change, 1996). The "retreat" strategy is the "abandonment of land and structures in vulnerable areas, and resettlement of inhabitants" (Intergovernmental Panel of Climate Change, 1990, p.146). The "accommodation" approach involves the acceptance of the possibility of property damage or loss. Finally, the "protection" strategy refers to the development of safeguarding measures to protect vulnerable coastal areas and infrastructures (Intergovernmental Panel of Climate Change, 1990). The protection adaptive response is also sub-classified into two types of measures: the "hard" structural options, and the "soft" structural options. The first option consists of the use of structures such as dikes, seawalls, groins, breakwaters, and barriers; while the second option includes the use of techniques such as beach nourishment, dune building, wetland/mangrove creation, and other types of ecologically sound solutions that could help increase coastal resilience (Intergovernmental Panel of Climate Change, 1990). 


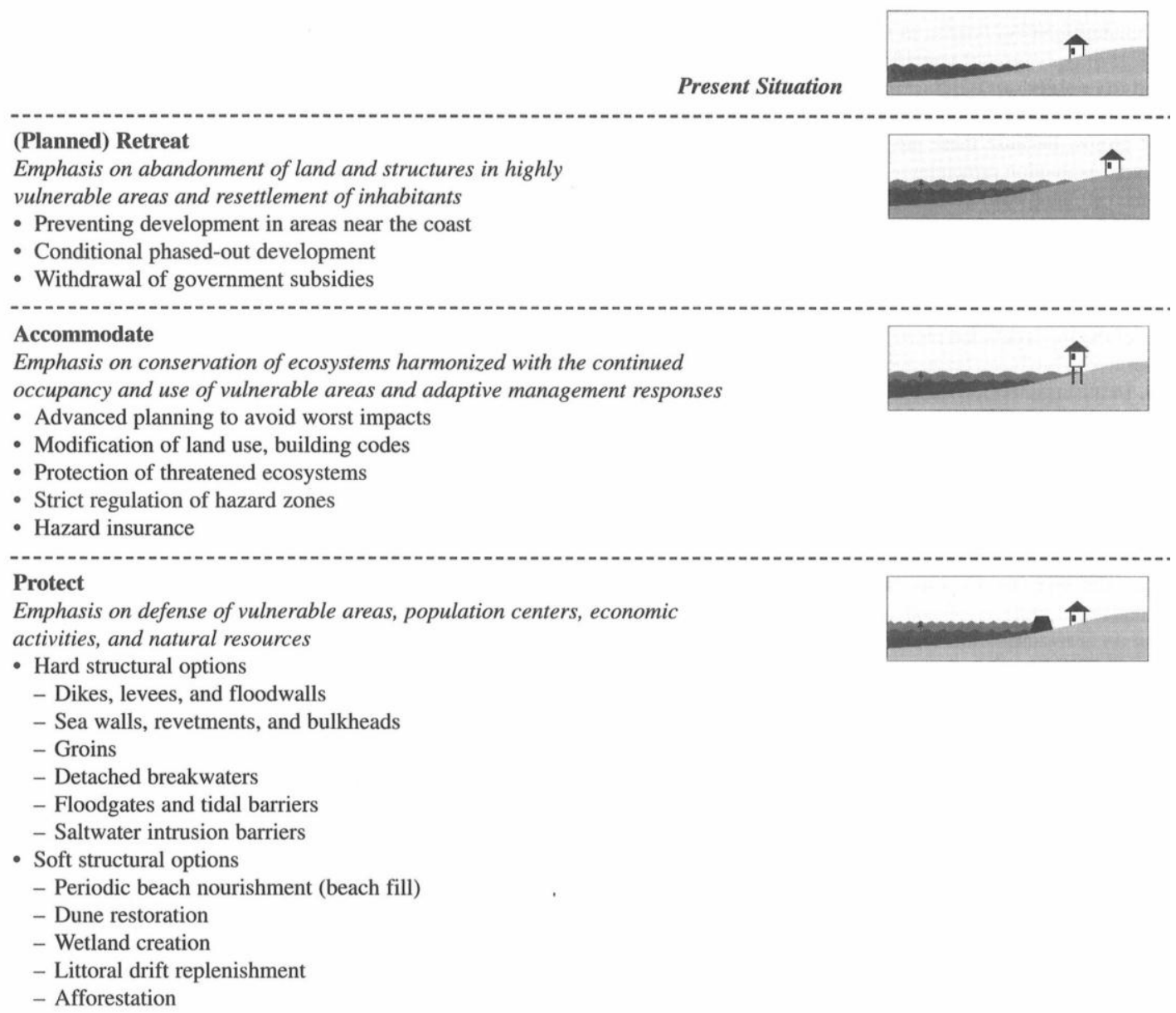

Figure 1. Response strategies to sea level rise (Intergovernmental Panel of Climate Change, 1990 as cited in Intergovernmental Panel of Climate Change, 1996, p. 313)

The purpose of this paper is to describe different types of "soft" structure options available to address sea level rise and, consequently, to protect coastal zones. The paper will first define what "hard" and "soft" structure options are, followed by examples of well-established "hard" and "soft" measures. Secondly, the paper will discuss the advantages and disadvantages of "soft" structure options using international examples. Advantages and drawbacks will be analyzed in the context of both environmental and social dimensions. The paper concludes with recommendations that coastal states and/or provinces might consider prior to selecting a soft structure option.

\section{"Hard" and "soft" structure options}

"Hard" structure options, which date from 1800s (Davison, Nicholls \& Leatherman, 1992), include the use or construction of dikes, levees, floodwalls, seawalls, revetments, bulkheads, groins, detached breakwaters, floodgates or tidal barriers, and saltwater intrusion barriers (Intergovernmental Panel of Climate Change, 1990). Infrastructure modification, such as elevations or relocations, are also included in this category (Intergovernmental Panel of 
Climate Change, 1990). However, these adaptation measurements have both advantages and disadvantages. For instance, in Egypt, an adaptation strategy evaluation suggested that breakwaters are highly efficient in terms of protecting coastal areas from sea level; however, the high cost of implementation makes it inaccessible to developing countries (El-Raey, Dewidar \& El-Hattab, 1999). Although seawalls have been shown to protect coastal infrastructures from sea level rise, they may also encourage further developments such as hotels and resorts, (Leatherman \& Beller-Simms, 1997), which in turn may limit the natural retreat of beaches, causing greater stress and potential destruction of coastal habitats (Hall \& Pilkey, 1991).

"Soft" structure options appear more suitable in coping with sea level rise, as this approach potentially provides environmentally-friendly protection, is aesthetically pleasing, and can usually be implemented within a reasonable budget (Black \& Mead, 2001; Gómez-Pina, Munoz-Perez, Ramírez \& Ley, 2002; Khalil, 2008). Examples of "soft" structure options include: beach nourishment, dune restoration, "afforestation" or reforestation, and "soft" engineering approaches such as the construction of artificial reefs or seaweeds (Intergovernmental Panel of Climate Change, 1990; Intergovernmental Panel of Climate Change, 1996). The benefit of using a "soft" structure option when compared with the "hard" counterpart (which only aims to protect coastal zones from sea level rise) is that it provides opportunities to recover natural features (e.g. beach nourishment) and/or simulates natural growing environments (e.g. "artificial mangroves"). Some of these measures have been applied for several years (e.g. beach nourishment), whilst others are still in the testing process (e.g. "dissipators reefs", "rotators reefs").

\section{"Soft" measures to cope with sea level rise in coastal zones}

\section{Beach Nourishment}

The Intergovernmental Panel of Climate Change (1990) describes beach nourishment as the action of "dredging sand from back bays, navigation channels, or offshore, or excavating material from a land-based source and placing it on the beach" (p.150). Beach nourishment is also defined as "the process of mechanically or hydraulically placing sand directly on an eroding shore to restore or form, and subsequently maintain, an adequate protective or desired recreational beach " (USACE, 1984, as cited in Greene, 2002, p.4). In developed countries, this type of adaptation measure is one of the oldest "soft" structures utilized to cope with beach erosion problems. For example, in the U.S., beach replenishment was first documented in 1922 (Davison et al., 1992). Similarly, in European countries, the practice of beach replenishment has been undertaken since 1951 (Hanson et al., 2002).

Several advantages are attributed to applying a beach nourishment strategy including helping to control coastal erosion. For example, Hanson et al. (2002), uses data from a detailed 
register of practices and objectives of beach nourishment plans in different European states, and demonstrates that this approach is successful only if sand filling is applied on a regular bases. Beach replenishment has also been shown to be ecologically sound for the sand crab (Uca tangeri), as the compression of sand by operational diggers is similar to the water pressures exerted during high tides (Herrera et al. 2010). From an economic perspective, the use of beach replenishment, as opposed to the installation of seawalls, is often more aesthetically pleasing, hence, there is a greater potential for tourism and associated economic benefits to occur if this approach is used. (Sawyer, 2011). From a social and cultural context, by protecting a beach from erosion and retreat, communities benefit from beach recreation, and landscape (Herrera et al., 2010). However, one of the best benefits from a well-nourished beach is the natural restoration of coastal dunes by eolian forces (Nordstrom, 2005)

However, there are also examples in the literature demonstrating the disadvantages of using beach nourishment approaches. From an ecological perspective, Peterson, Hickerson, and Johnson (2000) suggest that this soft structure option provokes a short-term change in the beach sedimentation by increasing the grain size in intertidal zones and, therefore, it reduces some prey macro-invertebrates density (e.g. Donax spp. and Emerita talpoida densities were reduced from $264-334 \mathrm{~m} 2$ and $137-159 \mathrm{~m} 2$ to $40-42 \mathrm{~m} 2$ and $0-4 \mathrm{~m} 2$, respectively). Yet, it is not possible to calculate those method's cumulative ecological consequences because of the low number of studies about long-term effects of beach nourishment (Speybroeck et al., 2005). Other drawbacks from beach replenishment are the potential change of beach dynamic and morphology (Nordstrom, 2008), and the high cost related to the continual filling of sand to make this option work over time (Esteves \& Finkl, 1998). Beach nourishment also requires heavy machinery and technology to dredge sand from the seafloor or land-based sources to provide the fill material, which in turn may disturb or destroy natural habitats (Herrera et al., 2010).

\section{Dune restoration}

Dune restoration or dune building is another type of "soft" structure approach that helps natural dunes recover from de-stabilizing forces. This restoration process "involves rebuilding sand dunes where they have been eliminated, increasing their area size dependent on the amount of space available, and allowing natural process to rework them into topographically diverse landforms with a variety of habitats" (Nordstrom, 2008, p. 49). Dunes are sensitive and mobile systems that have been degraded mainly because of massive tourism (Wilcock \& Carter, 1977; Gómez-Pina et al., 2002) and infrastructure development (Gomez-Pina et al., 2002, Nordstrom, 2008).

Since the early 1950 s, studies have been conducted to develop methods to recuperate dune systems. These methods include: eolian transportation (Nordstrom, 2005), sand-dune plantations, also categorized as "afforestation" (Sturgess, \& Atkinson, 1993), sand fence 
placement (Khalil, 2008), and sand transported by bulldozers (Wilcock \& Carter, 1977). However, the low success rate for this approach tends to suggest that restoration techniques must suit the specific dune characteristics (Wilcock \& Carter, 1977).

Healthy dunes offer coastal zones several positives benefits. For instance, when dunes are in a stable condition, they recover rapidly after a surge storm event, thus dune systems play a crucial role in protecting coastal areas from erosion, and storm surges (Wilcock \& Carter, 1977). Although dune-building programs are a long process they are successful in terms of morphological feature recuperation and vegetation composition recovery, including fauna biodiversity (Roze and Lemauviel, 2004). Another benefit attributed to healthy dunes is the flood protection it offers for both natural environments and coastal constructions. When dunes are restored properly, they maintain their form over long periods of time (Nordstrom, 2008) and, therefore, offer a longer, effective, and less costly mode of coastal protection (GomezPina et al., 2002). For example, the use of sand fences offers an inexpensive way to retain sand in a dune restoration system. These fences can be made of wooden slats, wooden pallets, recycled materials, branches, and "geojute" (geojute is a biodegradable fabric with porosity that allows sand to accumulate) (Miller, Thetford \& Yager, 2001; Khalil, 2008).

Sand dune restoration programs can provide tangible solutions to address sea level rise, however, they are not the panacea to cope with all its negative effects. For example, if sand dunes are not rebuilt properly, any gap could focus and enlarge the wave action during storm events leading to the further destabilization of the rebuilt dune base structure (Khalil, 2008). Also, similar to beach nourishment, dune building could modify the beach morphology and its internal pattern, thus, preventing the growing of the natural flora and fauna of the dune during the recovery process (Nordstrom, 2008)

\section{Afforestation and Reforestation}

Afforestation, and reforestation are other "soft" structure approaches used to adapt the coast to future climate change impacts. These options consist of "direct human-induced conversion of non-forest to forest land through planting, seeding, and/or the human-induced promotion of natural seed sources" (Nabuurs et al., 2007, p.550). By creating a forest belt, vulnerable coastal areas are potentially protected. For example, in tropical countries with low coastal areas, afforestation provides an accessible adaptation measure to reduce tidal surges, which are a very likely outcome from extreme events such as cyclones and typhoons. In Bangladesh, afforestation produces several benefits for both the coast and coastal communities. For example, the success of mangroves and salt-tolerance tree plantations have led to an increase in land value, and provided shelter and protection to wildlife and inhabitants during intense cyclone events (Saenger \& Siddiqi, 1993). Furthermore, afforestation and reforestation programs help to promote socio-economic advantages within the community. The creation of employment opportunities during the replanting phases (e.g. nursery, planting, and 
maintenance) has provided extra family income to local residents of coastal towns in Bangladesh (Iftekhar \& Islam, 2004).

Another benefit from this approach is that the physicochemical characteristics of the soil composition could be positively altered due to afforestation measures within shore areas. Shaifullah, Mezbahuddin, Sujauddin and Haque (2008), noted the changes in soil texture, $\mathrm{pH}$, moisture content, organic carbon, particle density, and total nitrogen at surface soil $(0-10 \mathrm{~cm})$, and subsurface $(10-45 \mathrm{~cm})$ in planted mangroves zones, and their results suggest that reducing the $\mathrm{pH}$ and soil nitrogen, and increasing the moisture and organic carbon, collectively, enhances the soil richness of the afforestated area and its surroundings. As a result, the natural growing of mangrove swamp flora creates a better habitat for the mangrove species, potentially leading to an increment in biomass (Mumby et al., 2004).

Several factors are important to consider when planting vegetation in coastal zones: (i) native or exotic, (ii) nitrogen-fixing capability, (iii) adaptability to burial, (iv) ability to spread underground (Nordstrom, 2008). For example, a study in South Africa highlights the wide adaptability of Ammophila arenaria to growth in different climate zones. This European plant has been utilized for dune stabilization and as a nursery species to native vegetation since the 1870s (Hertling \& Lubke, 1999). However, in New Zealand, the use of this species to promote dune systems along the coast triggered an opposite effect. Apparently, the rapid widespread and growth of A. arenaria in Manson Bay (1.4 ha in 1958, 17.8 ha in 1978, 74.9 ha in 1998) resulted in the displacement of the endemic coastal species Desmoschoenus spiralis (Hilton, Duncan, \& Jul, 2005). Additionally, areas that are exposed to high wind and wave action may not be the best sites for reforestation (Saenger \& Siddiqi, 1993). Restoration studies that have been conducted in high impact areas have resulted in seeding loss as a result of smothering and sediment accumulation of sand, clay, and silt (Saenger \& Siddiqi, 1993).

\section{Marine soft engineering technology}

The last "soft" structure option that will be discussed refers to the development of marine engineering technology. To date, "soft" engineering strategies offer a pool of different options to protect sensitive shore areas from sea level rise and coastal erosion. This option has been described as the creation of any structure that "may be found to increase resilience and reduce the vulnerability of coastal zone features that are under threat of degradation" (Intergovernmental Panel of Climate Change, 1990, p.149). Since the last century, "soft" engineering measures have attempted to address the growing coastal erosion trend. For instance, Turner and Leatherman (1997) describe a "beach dewatering" method that consists of "the artificial lowering of the water table beneath the top layer of the beach using a system of drains and pumps" (p. 1). The aim of this method is to reduce coastal erosion and to increase beach growth. Favourable results were reported in Denmark after the implementation of this technology (Turner \& Leatherman, 1997). The benefits of this "soft" structure technological 
approach include: beach stabilization, erosion control, and beach accretion (Turner \& Leatherman, 1997).

Another type of beach drainage system is the "pressure equalization module" (PEM). This marine engineering system consists of polyvinyl chlorine (PVC) pipes strategically placed within the up-rush zone to boost the vertical infiltration of seawater into the bed (Ghazali, 2005). Several benefits from the implementation of this technology in coastal areas include the increase of erosion-resistance and the negligible alteration of biological and physicochemical beach characteristics (Seng, Ghazali \& Lim, 2009; Ghazali, 2005).

In addition to beach dewatering and the pressure equalization module, the "filled geosynthetic container system" offers another alternative to cope with sea level rise. This technology consists of a container (bags or tubes) made of geotextile or geomembrane that is filled with sand or salty water, which are then placed on the coastal zones or underwater (Harris \& Sample, 2009). Previously, this approach was considered a temporary measure to protect seashore areas from storm surges. However, the re-design of this technique and integrating other new technology has resulted in making this soft structure more resistant and durable over greater time periods. The use of these containers has been widely used in the coastal zones of United States (Harris \& Sample, 2009), Australia (Jackson et al., 2004), and the Republic of Korea (Shin \& Oh, 2007) with positive outcomes in terms of coastal protection and ecological enhancement.

Bio-technical structures are "soft" measures that both simulate natural coastal structures and enhance the growth of marine flora. For instance, "artificial seagrass systems", when securely attached to the seafloor, play a crucial role in enhancing fish habitats (Ismail, 2003; Shahbudin et al., 2011) and reducing the velocity of the water current (Ghazali, 2005). Similar to artificial sea grass habitats, "artificial mangrove roots" are another promising type of bio-technical structure. Based on the natural characteristics of the mangroves and their function as an efficient wave breaker, artificial structures provide protection to the shoreline developments in an event of storm surges, and also protect young mangrove seedlings from being washed away due to wave action (Fatimah, Wahab \& Ismail, 2008).

Finally, the concept of "wave rotation" has been introduced as a new approach for developing artificial reefs. This technology seeks to redirect the wave rotations to minimize coastal erosion by re-aligning the angle of the breakpoint. To date, two offshore reefs have been developed to minimize the effects of wave-breaking and, therefore, coastal erosion due to this friction. These are "dissipators" and "rotators." According to Black and Mead (2001), numerical models support the creation of artificial reefs for the protection of the coasts and beaches. For example, "'dissipators reefs' reduce the wave energy at the shoreline by wave breaking" (p.2), while "rotators" reefs "reduce the long-shore currents to stabilize the coast" (p.2) (Black \& Mead, 2001). As these structures are submerged in the water, they also create aesthetically 
and environmentally pleasing solutions, which potentially will result in positive socio-economic benefits, such as more recreational areas (Black \& Mead, 2001).

\section{Summary and Recommendations}

According to the Intergovernmental Panel of Climate Change (1990), coastal zones will eventually face an increase in sea level that could have irreversible repercussions. Thus, there is an urgent need provide environmentally sound approaches to protect and enhance coastal zones because these are important areas that represent the livelihoods of many communities (e.g. fisheries, tourism, and coastal development).

This paper has described several "soft" structure options that could be used to cope with sea level rise. Some of these approaches have been used, are being revised, and/or are still being utilized as protection strategies in coastal zones. Specific examples that integrate marine engineering biotechnology appear to be the most ecologically sound due to their design, functionality, and long-term duration. Many of these "soft" structure approaches also provide options that could assist with the recovery of natural features and support related fauna and flora along the coast. The conclusion of this paper is that from a coastal protection perspective, "soft" structure options do present positives outcomes and offer very applicable solutions to cope with sea level rise.

Based on the findings and discussion in this paper the following recommendations that could support soft structure approaches are suggested:

- Environmental impact assessments (EIA) should be conducted prior to the implementation of a beach nourishment structure. Development should only continue if the EIA indicates that the impacts are not severe. Specific guidelines or policy must be developed to aid with the recovery of damaged or degraded coastline while at the same time being cautious about secondary environmental or economic impacts.

- Countries and/or provinces that have coastal zones as part of their jurisdiction should consider the positive benefits of investing in dune restoration programs. The natural capacity of sand dunes to mitigate coastal erosion and to aid in the recovery after storm surges makes this option a suitable strategy to cope with sea level rise and storm surges.

- When considering using "afforestation" as a "soft" measure approach to protect shore areas, experiments in the laboratory may be necessary prior to introducing a potential exotic species that could later become a biological pest. For example, introduce exotic fauna or flora under extreme consequences may cause the eradication of native 
species. As such, scientific research and policies must be considered before applying these types of planting programs.

- Marine "soft" engineering measures are scientifically robust alternatives that seek to protect shore zones while recovering beach characteristics. Including them in coastal protection programs to address sea level rise could require a bigger budget for any country. However, governments should consider such an investment because marine "soft" engineering measures have proven to be long-lasting and ecological sound options.

\section{Acknowledgements}

The Author would like to thank the Course Instructor and Director of the Marine Affairs Program, Dalhousie University, Dr Lucia M. Fanning for her constructive comments in this paper, and Liz Wilson (ID PhD candidate) for her continuing interest in, and valuable observations of, this essay. 


\section{References}

Black, K. \& Mead, S. (2001). Wave rotation for coastal protection. In Proceedings of the 15th Australasian Coastal and Ocean Engineering Conference, (pp. 120-127). Retrieved from:

http://gbr.020.com.au/WaveRotator\%20coastal\%20protection.pdf

Bosello, F., Roson, R., \& Tol, R. (2007). Economy-wide estimates of the implications of climate change: Sea level rise. Environmental and Resource Economics, 37(3), 549-571. http://dx.doi.org/10.1007/s10640-006-9048-5

Davison, A., Nicholls, R., \& Leatherman, S. (1992). Beach nourishment as a coastal management tool: an annotated bibliography on developments associated with the artificial nourishment of beaches. Journal of Coastal Research, 8(4), 984-1022. Retrieved from http://www.jstor.org.ezproxy.library.dal.ca/stable/pdfplus/4298052.pdf?acceptTC=true

El-Raey, M., Dewidar, K., \& El-Hattab, M. (1999). Adaptation to the impacts of sea level rise in Egypt. Mitigation and Adaptation Strategies for Global Change, 4(3-4), 343-361. http://dx.doi.org/10.1023/A:1009684210570

Esteves, L., \& Finkl, C. (1998). The problem of critically eroded areas (CEA); an evaluation of Florida beaches. Journal of Coastal Research, 26, 11-18. Retrieved from http://www.vliz.be/imisdocs/publications/40784.pdf

Fatimah, E., Wahab, A. K. A., \& Ismail, H. (2008). Numerical modeling approach of an artificial mangrove root system (ArMS) submerged breakwater as wetland habitat protector. Proceeding of the seventh international conference on coastal and port engineering, PIANC-COPEDEC VII, United Arab Emirates, 88, 1-20. Retrieved from http://www.flow3d.com/pdfs/tp/wat env tp/FloSci-Bib43-08.pdf

Ghazali, N. H. M. (2005). New innovations and technologies in coastal rehabilitation. Proceeding of the International Conference on Innovations and Technologies in Oceanography for Sustainable Development, Malaysia. Retrieved from http://test.esmology.com/water/images/pdf/innovation CoastalRehab.pdf

Gómez-Pina, G., Munoz-Perez, J. J., Ramírez, J. L., \& Ley, C. (2002). Sand dune management problems and techniques, Spain. Journal of Coastal Research, 36(36), 325-332. Retrieved from http://www.globalrestorationnetwork.org/uploads/files/LiteratureAttachments/289 sanddune-management-problems-and-techniques---spain.pdf 
Gornitz, V., Couch, S., \& Hartig, E. K. (2002). Impacts of sea level rise in the New York City metropolitan area. Global and Planetary Changes 32(1), 61-88. http://dx.doi.org/10.1016/S0921-8181(01)00150-3

Greene, K. (2002, November). Beach nourishment: a review of the biological and physicallmpacts. Retrieved from http://www.vliz.be/imisdocs/publications/41411.pdf

Hall, M. J., \& Pilkey, O. H. (1991). Effects of hard stabilization on dry beach width for New Jersey. Journal of Coastal Research, 7(3), 771-785. Retrieved from http://www.poweryourmind.com/WebFiles/PDFs/psds Effects Stabilization 1991.pdf

Hanson, H., Brampton, A., Capobianco, M., Dette, H., Hamm, L., Laustrup, C., . . Spanhoff, R. (2002). Beach nourishment projects, practices, and objectives - a European overview. Coastal Engineering, 47(2), 81-111. http://dx.doi.org/10.1016/S0378-3839(02)00122-9

Harris, L. E. \& Sample, J. W. (2009). The evolution of multi-celled sand-filled geosynthetic systems for coastal protection and surfing enhancement. Reef Journal 1(1). Retrieved from http://www.thereefjournal.com/files/1. Harris and Sample.pdf

Herrera, A., Gomez-Pina, G., Fages, L., de La Casa, A., \& Munoz-Perez, J. J. (2010). Environmental impact of beach nourishment: a case study of the Rio San Pedro beach (SW Spain). The Open Oceanography Journal, 4(1), 32-41. http://dx.doi.org/10.2174/1874252101004010032

Hertling, U., \& Lubke, R. (1999). Use of Ammophila arenaria for dune stabilization in South Africa and its current distribution-perceptions and problems. Environmental Management, 24(4), 467-482. http://dx.doi.org/10.1007/s002679900247

Hilton, M., Duncan, M., \& Jul, A. (2005). Processes of Ammophila arenaria (Marram grass) invasion and indigenous species displacement, Stewart Island, New Zealand. Journal of Coastal Research, 21(1), 175-185. http://dx.doi.org/10.2112/01041.1

Iftekhar, \& Islam, M. (2004). Managing mangroves in Bangladesh: a strategy analysis. Journal of Coastal Conservation, 10(1), 139-146. http://dx.doi.org/10.1652/1400-0350(2004)010[0139:MMIBAS]2.0.CO;2 
Intergovernmental Panel of Climate Change. (1990). Coastal Zone Management. In Climate change: the IPCC response strategy (1990) (chap.5). Retrieved from http://www.ipcc.ch/ipccreports/far/wg III/ipcc far wg III chapter 05.pdf

Intergovernmental Panel of Climate Change. (1996). Climate change 1995: impacts, adaptations and mitigation of climate change: scientific technical analysis. Retrieved from

http://www.ipcc.ch/ipccreports/sar/wg II/ipcc sar wg II full report.pdf

Ismail, H. (2003). Valued-added shore protection structures for enhancement of the marine ecosystem services. Proceeding of the 2003 Technical Seminar on Shoreline Management, Malaysia. Retrieved from http://utm-my.academia.edu/Hadibahlsmail/Papers/479281/Value-Added Shore Protection Structures for the Enhancement of Marine Ecosystem Services

Jackson, L., Reichelt, R. E., Restall, S., Corbett, B., Tomlinson, R., \& McGrath, J. (2004). Marine ecosystem enhancement on a geotextile coastal protection reef: narrowneck reef case study. Proceeding of the $29^{\text {th }}$ International Conference on Coastal Engineering, Portugal, 4, 3940-3952. http://dx.doi.org/10.1142/9789812701916 0318

Khalil, S. M. (2008). The use of sand fences in barrier island restoration: experience on the Louisiana Coast. Retrieved from http://www.dtic.mil/cgi-bin/GetTRDoc?AD=ADA479139\&Location=U2\&doc= GetTRDoc.pdf

Leatherman, S. P, \& Beller-Simms, N. (1997). Sea-level rise and small island states: an overview. Journal of Coastal Research, 24, 1-16. Retrieved from http://www.jstor.org.ezproxy.library.dal.ca/stable/10.2307/25736084

Mato, Y., Isobe, T., Takada, H., Kanehiro, H., Ohtake, C., \& Kaminuma, T. (2001). Plastic resin pellets as a transport medium for toxic chemicals in the marine environment. Environmental Science \& Technology, 35(2), 318-324. http://dx.doi.org/10.1021/es0010498

Meehl, G.A., Stocker, T.F., Collins, W.D., Friedlingstein, P., Gaye, A.T., Gregory, J.M.,...Zhao, Z. C. (2007). 2007: global climate projections. In Climate Change 2007: The Physical Science Basis. Contribution of Working Group I to the Fourth Assessment Report of the Intergovernmental Panel on Climate Change (chap.10). Retrieved from http://www.ipcc.ch/pdf/assessment-report/ar4/wg1/ar4-wg1-chapter10.pdf 
Miller, D., Thetford, M., \& Yager, L. (2001). Evaluation of sand fence and vegetation for dune building following overwash by hurricane opal on santa rosa island, florida. Journal of Coastal Research, 17(4), 936-948. Retrieved from http://www.jstor.org.ezproxy.library.dal.ca/stable/pdfplus/4300253.pdf

Mumby, P. J, Edwards, A. J., Arias-Gonzalez, E., Lindeman, K. C., Blackwell, P. G., Gall, A.,...Llewellyn, G. (2004). Mangroves enhance the biomass of coral reef fish communities in the Caribbean. Nature, 427, 533-536. http://dx.doi.org/10.1038/nature02286

Muniz, P., Danulat, E., Yannicelli, B., Garcia-Alonso, J., Medina, G., \& Bicego, M. C. (2004). Assessment of contamination by heavy metals and petroleum hydrocarbons in sediments of Montevideo Harbour (Uruguay). Environment International, 29(8), 10191028.

http://dx.doi.org/10.1016/S0160-4120(03)00096-5

Nabuurs, G.J., Masera, O., Andrasko, K., Benitez-Ponce, P., Boer, R., Dutschke, M.,...Zhang, X. (2007). Forestry. In Climate Change 2007: Mitigation. Contribution of Working Group III to the Fourth Assessment Report of the Intergovernmental Panel on Climate Change (chap.9). Retrieved from http://www.ipcc.ch/pdf/assessment-report/ar4/wg3/ar4-wg3-chapter9.pdf

Nordstrom, K. (2005). Beach nourishment and coastal habitats: research needs to improve compatibility. Restoration Ecology, 13(1), 215-222. http://dx.doi.org/10.1111/j.1526-100X.2005.00026.x

Nordstrom, K. (2008). Beach and dune restoration. United kingdom: Cambridge University Press.

Peterson, C. H., Hickerson, D., \& Johnson, G. (2000). Short-term consequences of nourishment and bulldozing on the dominant large invertebrates of a sandy beach. Journal of Coastal Research, 16(2), 368-378. Retrieved from http://www.jstor.org.ezproxy.library.dal.ca/stable/pdfplus/4300045.pdf

Roze, F., \& Lemauviel, S. (2004). Sand dune restoration in north Brittany, France: A 10-year monitoring study. Restoration Ecology, 12(1), 29-35. http://dx.doi.org/10.1111/j.1061-2971.2004.00264.x

Saenger, P., \& Siddiqi, N. (1993). Land from the sea: The mangrove afforestation program of Bangladesh. Ocean and Coastal Management, 20(1), 23-39. 
Sarwar, G., \& Khan, M. (2007). Sea level rise: a threat to the coast of Bangladesh. Internationales Asien Forum. International Quarterly for Asian Studies, 38(3), 375-400. Retrieved from http://search.proquest.com.ezproxy.library.dal.ca/docview/212217104/fulltextPDF?acco untid=10406

Sawyer, L. (2011, April 1). Seawalls in Samoa: a look at their environmental, social and economic implications. Retrieved from http://digitalcollections.sit.edu/cgi/viewcontent.cgi?article=2084\&context=isp collection

Seng, T. K., Ghazali, N. H. M., \& Lim, O. H. (2009, August). Rehabilitation of the beach at Teluk Cempedak, Pahang, using pressure equalisation modules (PEM) System. Jurutera. Retrieved from http://myiem.org.my/assets/download/Feature0809.pdf

Shahbudin, S., Jalal, K.C.A., Kamaruzzaman, Y., Mohammad- Noor, N., Chit Dah, T., \& Akbar John, B. (2011). Artificial seagrass: a habitat for marine fishes. Journal of Fisheries and Aquatic Science, 6(1), 85-92.

http://dx.doi.org/10.3923/jfas.2011.85.92

Shaifullah, K. M., Mezbahuddin, M., Sujauddin, M., \& Haque, S M. S. (2008). Effects of coastal afforestation on some soil properties in Lakshmipur coast of Bangladesh. Journal of Forestry Research, 19(1), 32-36.

http://dx.doi.org/10.1007/s11676-008-0005-8

Shin, E. C., \& Oh, Y. I. (2007). Coastal erosion prevention by geotextile tube technology. Geotextiles and Geomembranes, 25(4-5) 264-277. http://dx.doi.org/0.1016/i.geotexmem.2007.02.003

Speybroeck, J., Bonte, D., Courtens, W., Gheskiere, T., Grootaert, P., Maelfait, J. P., ...Degraer, S. (2005). How may beach nourishment affect the sandy beach ecosystem? The case of Belgian beaches. Proceedings of the Dunes and Estuaries 2005: International Conference on Nature Restoration Practices in European Coastal Habitats, Belgium, 19, 557-568. Retrieved from http://www.google.ca.ezproxy.library.dal.ca/url?sa=t\&rct=i\&q=how\%20may\%20beach\% 20nourishment\%20affect\%20the\%20sandy\%20beach\%20ecosystem\%3F\%20the \%20c ase \%20of\%20belgian\%20beaches\&source $=$ web\&cd $=1 \&$ sqi $=2 \&$ ved $=0$ CBoQFjAA\&url=ht tp\%3A\%2F\%2Fwww.vliz.be\%2Fimisdocs\%2Fpublications\%2F73882.pdf\&ei=P G5TsG gNo3jggez94n2DQ\&usg=AFQjCNEjYFtektCOMOlpHecaJyoAp5tmwg\&cad=rja 
Sturgess, P., \& Atkinson, D. (1993) The clear-felling of sand-dune plantations: soil and vegetational processes in habitat restoration. Biological Conservation, 66, 171-183. http://dx.doi.org/10.1016/j.bbr.2011.03.031

Turner, I. L., \& Leatherman, S. P. (1997). Beach dewatering as a 'soft' engineering solution to coastal erosion: a history and critical review. Journal of Coastal Research, 13(4), 10501063. Retrieved from http://www.jstor.org.ezproxy.library.dal.ca/stable/pdfplus/4298714.pdf

Tunstall, S., Tapsell, S., Green, C., Floyd, P., \& George, C. (2006). The health effects of flooding: social research results from England and Wales. Journal Of Water And Health, 4(3), 365-380. Retrieved from http://www.iwaponline.com/jwh/004/0365/0040365.pdf

Wilcock, F. A. \& Carter, W. G. (1977). An environmental approach to the restoration of badly eroded sand dunes. Biological Conservation, 11(4), 279-291. http://dx.doi.org/10.1016/0006-3207(77)90041-6 